\title{
STRATEGI PENGEMBANGAN DESA WISATA GUBUGKLAKAH
}

\author{
A.Yusuf Kholil dan Ninin Khoirunnisa \\ Program Studi Agribisnis \\ Universitas Tribhuwana Tunggadewi Malang \\ Email: yusufyuzasif@gmail.com
}

\begin{abstract}
ABSTRAK
Tujuan pertama dalam penelitian ini adalah mengidentifikasi dan menganalisis potensi daerah Desa Gubugklakah. Tujuan kedua adalah mengidentifikasi dan menganalisis lingkungan internal dan eksternal Desa Gubugklakah yang menjadi kekuatan, kelemahan, peluang dan ancaman. Tujuan terkahir dalam penelitian ini adalah menentukan strategi yang tepat untuk diterapkan dalam pengembangan Desa Wisata Gubugklakah sebagai desa wisata. Metode analisis data yang digunakan yaitu analisis deskriptif dan analisis kualitatif. Analisis deskriptif digunakan untuk menganalisis potensi Desa Gubugklakah dan mengidentifikasi faktor utama pada faktor internal (IFE) dan eksternal (EFE) sedangkan dalam analisis kualitatif menggunakan analisis SWOT yang berupa matriks IE dan matriks SWOT. Untuk menganalisis strategi pengembangan Desa Gubugklakah menggunakan analisis QSPM.
\end{abstract}

\section{Kata kunci: evaluasi faktor internal, evaluasi faktor eksternal, matriks SWOT, matriks QSPM.}

The first objective of this research is to identify and analyze potential areas Gubugklakah Village. The second objective is to identify and analyze the internal and external environment Gubugklakah Village of the strengths, weaknesses, opportunities and threats. The last destination of this research is to determine the right strategy to be applied in the development of tourism Gubugklakah Village as a tourist village. Data analysis method used is descriptive analysis and qualitative analysis. Descriptive analysis was used to analyze the potential of the Gubugklakah Village and identify the main factors on internal factors (IFE) and external (EFE) whereas in qualitative analysis using SWOT analysis in the form of a matrix IE and SWOT matrix. To analyze the development strategy of the Gubugklakah Village use QSPM analysis.

Keywords: internal factors evaluation, external factors evaluation, SWOT matrix, QSPM matrix.

\section{PENDAHULUAN}

Negara Indonesia mempunyai

beraneka macam potensi wisata yang dapat dijadikan sebagai daya tarik wisata sehingga menjadi kesenangan tersendiri bagi para wisatawan, seperti wisata alam dan budaya yang begitu beraneka ragam. Pulau Jawa merupakan salah satu pulau yang berada di Indonesia yang memiliki karakter masyarakat pedesaan yang ramah tamah. Dengan posisi geografis paling timur di pulau Jawa, Jawa Timur memiliki Kabupaten Malang sebagai kota yang berpotensi memiliki banyak tempat wisata. Diantara banyaknya potensi wisata yang ada di Kabupaten malang, terdapat salah satu kecamatan yakni Kecamatan Poncokusumo yang merupakan kecamatan 
di wilayah Malang Timur, yang berbatasan langsung dengan Kabupaten Lumajang, Pasuruan dan Probolinggo serta bersinggungan langsung dengan Kawasan Bromo Tengger Semeru (BTS). Kecamatan Poncokusumo ditetapkan sebagai Kecamatan Agropolitan, dimaksudkan bahwa Kecamatan Poncokusumo sebagai kawasan pertanian, perkebunan dan wisata. Selain itu, di Kecamatan Poncokusumo terdapat beberapa desa yang memiliki potensi sebagai desa wisata.

Menurut Pariwisata Inti Rakyat (PIR) yang dimaksud dengan Desa Wisata adalah suatu kawasan pedesaan yang menawarkan keseluruhan suasana yang mencerminkan keaslian pedesaan baik dari kehidupan sosial ekonomi, sosial budaya, adat istiadat, keseharian, memiliki arsitektur bangunan dan struktur tata ruang desa yang khas, atau kegiatan perekonomian yang unik dan menarik serta mempunyai potensi untuk dikembangkan. Desa Gubugklakah merupakan sebuah desa yang berada di Kecamatan Poncokusumo Kabupaten Malang. Sejak beberapa tahun ini, perkembangan wisata di Gubugklakah terus menunjukkan perkembangan seiring dengan ramainya wisatawan yang berkunjung ke Gunung Bromo dan Gunung Semeru. Selain berwisata ke gunung, wisatawan juga dapat berwisata di beberapa destinasi yang lokasinya berada di Gubugklakah. Di antaranya yaitu Agrowisata Apel, Coban
Pancut, dan Coban Gereja. Akan tetapi, untuk dua coban tersebut masih terkendala akses jalan yang hanya berupa jalan setapak. Desa Wisata Gubugklakah juga memasukkan tujuan wisata yang lain seperti wisata arung jeram dan river tubbing di Sungai Ledok Amprong, dan wisata air terjun Coban Pelangi. Untuk rencana destinasi wisata ke depan di Desa Wisata Gubugklakah akan menambah destinasi wisata dengan adanya kawasan wisata agropolitan sapi perah. Produk susu dari sapi perah nantinya akan diolah menjadi beragam produk olahan.

Berdasarkan dari hal-hal tersebut diatas, masih banyak sekali potensi-potensi lain dari Desa Gubugklakah untuk lebih dieksplor dan diperlukan suatu strategi yang tepat agar segala potensi yang dimiliki dapat dikembangkan dan dikenal masyarakat jauh lebih luas. Melalui pembangunan dan pengembangan desa wisata, diharapkan dapat menopang konsep pengembangan pariwisata di Kecamatan Poncokucumo, Kabupaten Malang bahkan Desa Gubugklakah tidak hanya sebagai perlintasan melainkan destinasi utama wisata serta dapat membuka akses pasar baru bagi berbagai komoditas lokal dan penciptaan lapangan kerja baru serta peningkatan kesejahteraan masyarakat desa.

Mengacu pada uraian latar belakang diatas, maka perumusan masalah sebagai 
dasar dalam pengembangan penelitian ini adalah:

1. Bagaimana potensi wisata di Desa Gubugklakah?

2. Apa saja yang menjadi kekuatan, kelemahan, peluang dan ancaman dalam pengembangan wisata di Desa Gubugklakah?

3. Bagaimana strategi yang tepat untuk pengembangan Desa Wisata Gubugklakah?

4. Bagaimana menyusun Program Rencana Aksi dalam hal pengembangan Desa Wisata Gubugklakah?

Berdasarkan uraian dari rumusan masalah tersebut di atas, maka tujuan dalam penelitian ini adalah:

1. Untuk mengetahui potensi wisata di Desa Gubugklakah

2. Untuk mengetahui kekuatan, kelemahan, peluang dan ancaman dalam hal pengembangan wisata di Desa Gubugklakah

3. Untuk mengetahui strategi yang tepat untuk pengembangan Desa Wisata Gubugklakah

4. Untuk mengetahui dan menyusun Program Rencana Aksi dalam hal pengembangan wisata di Desa Gubugklakah.

\section{METODE PENELITIAN}

\section{Subjek, Objek dan Tempat Penelitian}

Subjek dalam penelitian ini adalah para pemerintah desa, pengelola LADESTA Gubugklakah dan masyarakat Desa Gubugklakah. Objek dalam penelitian ini adalah Strategi pengembangan yang dilakukan dalam hal pengembangan wisata di Desa Gubugklakah. Penentuan lokasi penelitian dilakukan secara sengaja (purposive) yaitu Desa Gubugklakah, Kecamatan Poncokusumo, Kabupaten Malang dengan pertimbangan bahwa daerah ini memiliki banyak potensi wisata yang memungkinkan ketersediaan data untuk keperluan penelitian ini.

\section{Desain Penelitian}

Metode analisis data yang digunakan dalam penelitian ini yaitu analisis deskriptif dan analisis kualitatif. Analisis deskriptif digunakan untuk menganalisis potensi Desa Gubugklakah, Kecamatan Poncokusumo, Kabupaten Malang dan mengidentifikasi faktor utama untuk memberikan bobot pada faktor yang sudah kita tentukan terdiri dari kekuatan, peluang, kelemahan dan ancaman dengan membandingkan antara baris dan kolom dari masing-masing variabel pada faktor internal (IFE) dan eksternal (EFE). Analisis kualitatif dalam penelitian ini menggunakan analisis SWOT yang berupa matriks IE dan matriks SWOT yang digunakan untuk menganalisis strategi 
pengembangan desa wisata dan untuk perumusan strategi terakhir dengan menggunakan analisis QSPM.

\section{Metode Penarikan Sampel}

Metode penentuan responden dalam penelitian termasuk dalam non-probability sampling karena tidak memberi kemungkinan yang sama bagi tiap unsur populasi untuk dipilih. Dalam penelitian ini, peneliti menggunakan teknik critical case sampling untuk responden faktor internal dan teknik accidental sampling untuk responden faktor eksternal.

\section{a. Teknik Critical Case Sampling}

Peneliti menggunakan teknik ini dengan pertimbangan bahwa responden harus memiliki tingkat penguasaan yang tinggi terhadap bidang yang akan diteliti sekaligus permasalahan yang ada di Desa Gubugklakah, Kecamatan Poncokusumo, Kabupaten Malang. Responden yang dimaksud dalam penelitian ini adalah para pemerintah desa, pengelola ladesta serta tokoh masyarakat Desa Gubugklakah yang mengerti dan mendalami keadaan dari desa tersebut DAN Dinas Kebudayaan dan Pariwisata Kabupaten Malang.

\section{b. Teknik Accidental Sampling}

Dalam penelitian ini, populasinya adalah pengunjung atau wisatawan Desa Wisata Gubugklakah dengan jumlah yang tidak diketahui secara pasti. Tidak diketahui secara pasti karena pengunjung yang datang setiap hari berbeda jumlahnya sehingga tidak bisa diprediksikan berapa orang yang akan berkunjung. Teknik pengambilan sampel yang diambil berdasarkan pertimbangan bahwa populasi yang ada tidak diketahui secara pasti jumlahnya sehingga menggunakan Accidental Sampling yaitu pengambilan sampel yang dilakukan kepada siapa saja yang kebetulan ada (Soeratno dan Lincolin,2008).

\section{HASIL DAN PEMBAHASAN}

\section{Gambaran Umum Lokasi Penelitian}

Desa Gubugklakah merupakan sebuah desa yang terletak di sebelah timur Kecamatan Poncokusumo Kabupaten Malang dengan luas wilayah sekitar 384 ha. Desa Gubugklakah terdiri dari daerah wilayah permukiman penduduk dan lahan daerah pertanian dengan jumlah penduduk Desa Gubugklakah sekitar 3.772 jiwa. Jarak desa dari propinsi sejauh $127 \mathrm{~km}$, jarak dari kabupaten sejauh $35 \mathrm{~km}$ dan jarak dari kecamatan sejauh $12 \mathrm{~km}$. Adapun batasbatas Desa Gubugklakah berbatasan dengan, batas utara : Desa Duwet; batas Timur: Desa Ngadas; batas Selatan : Desa Poncokusumo; batas Barat: Desa Wringinanom

Desa Gubugklakah berada di kaki Gunung Bromo dengan ketinggian 9001200 m dpl dan merupakan salah satu desa yang terletak di jalur utama menuju pendakian Gunung Bromo dan Semeru. Rata-rata curah hujan di Desa Gubugklakah 
berkisar antara 2000-3000 $\mathrm{mm} /$ tahun dengan suhu rata-rata $16^{\circ} \mathrm{C}$. Suhu udara yang berada dibawah $20^{\circ} \mathrm{C}$ ini menyebabkan Desa Gubugklakah memiliki suhu dingin dan baik untuk pengembangan pertanian dan wisata di daerah dataran tinggi.

Masyarakat Desa Gubugklakah merupakan masyarakat keturunan asli Suku Tengger, yang biasa dikenal tinggal dan bermukim di bawah kaki Gunung Bromo. Masyarakat Suku Tengger mempunyai hubungan yang khas dalam hubungan kekerabatan. Garis keturunan masyarakat Suku Tengger adalah berdasarkan pada prinsip bilateral yaitu garis keturunan pihak ayah dan ibu. Ada tiga macam kelompok kekerabatan dalam masyarakat Suku Tengger.

\section{Lembaga Desa Wisata (LADESTA)} Gubugklakah

Lembaga Desa Wisata Gubugklakah atau yang biasa disingkat dengan LADESTA Gubugklakah merupakan sebuah lembaga atau organisasi dari para masyarakat Desa Gubugklakah. Lembaga ini merupakan pondasi dari pengembangan wisata di Desa Gubugklakah Kecamatan Poncokusumo Kabupaten Malang. Dari sinilah, para pemuda yang ada di rest area dan para pemuda yang berjualan di Coban Pelangi atas usulan dari mahasiswa KKN Universitas Gajah Mada 2010 Unit 155 menggabungkan ide atau gagasan mereka untuk membentuk sebuah lembaga yang bertujuan mengembangkan potensi alam dan mensejahterakan masyarakat desa. Dari ide atau gagasan mereka yang menganggap bahwa desa mereka sebagai perlintasan saja, maka pada tanggal 20 Agustus 2010 mereka mendirikan sebuah lembaga yang dinamakan Lembaga Desa Wisata Gubugklakah (LADESTA) Gubugklakah. Lembaga ini tidak hanya berdiri sendiri melainkan dibantu oleh beberapa pihak dan atas kerjasama dari para perangkat desa, Karang Taruna, LPMD, BPD dan dukungan dari Mahasiswa KKN UGM 2010 Unit 155. Setelah satu tahun berdiri, dengan dibantu oleh mahasiswa KKN UGM 2011 Unit 11, proses legalisasi di urus dan pada tanggal 4 Agustus 2011 di bantu oleh teman-teman KKN UGM 2011 Unit 11 Lembaga Desa Wisata Gubugklakah ini mendapatkan legalisasi hukum.

\section{Analisis Potensi Desa Gubugklakah}

Suatu desa dapat dikatakan memiliki objek dan daya tarik wisata sebagai objek tujuan wisata apabila objek tersebut memiliki beberapa unsur-unsur daerah tujuan wisata atau (DTW), keempat unsur tersebut adalah : Attraction, Accessibility, Amenities dan Anciliary service. Dalam mendukung pengembangan potensi Desa Wisata Gubugklakah, maka dengan adanya unsur-unsur tersebut dapat 
dilihat potensi yang ada pada Desa Gubugklakah. Potensi yang dimiliki Desa Gubugklakah adalah sebagai berikut:

\section{a. Attraction (Atraksi)}

Beberapa hal yang dapat menjadi daya tarik ( atraksi ) dari Desa Gubugklakah ini adalah Pemandangan alam pegunungan yang masih sangat asli karena berada di kompleks kawasan Taman Nasional Bromo Tengger dan Semeru; Adanya lahan pertanian, air terjun, sungai dan hutan yang masih asli dan tidak tercemar; Suasana pedesaan yang aman dan tentram; Memiliki produk wisata atau paket-paket wisata berupa: Agrowisata apel, agrowisata sapi perah, Rafting dan tubbing ,kegiatan outbond dan perkemahan, kegiatan bercocok tanam sayur dan buah; Kesenian berupa Karawitan, Campur Sari, Al Banjari dan Terbangan, Pencak Silat, Tayuban, Jaran kencak, Kuda Lumping, Bantengan dan Tari Topeng sedangkan kesenian berbentuk sebuah upacara terdiri dari upacara karo dan sadranan yang merupakan upacara asli dari keturunan Suku Tengger.

\section{b. Accesibility (Aksesibiltas)}

Beberapa faktor aksesibiltas yang ada di Desa Gubugklakah adalah kondisi jalan menuju Desa Gubugklakah merupakan jalan yang beraspal yang sudah bagus dan ada penerangan jalan; Jarak Desa Gubugklakah dari propinsi sejauh 127 km, jarak dari kabupaten sejauh $35 \mathrm{~km}$ dan jarak dari kecamatan sejauh $12 \mathrm{~km}$; Untuk menuju Desa Gubugklakah transportasi yang dapat digunakan dapat berupa motor atau mobil pribadi dari semua jenis kendaraan bisa melewati Desa Gubugklakah, sedangkan transportasi untuk melakukan wisata pendakian atau outbond telah disediakan berupa motor tril dan mobil jeep.

\section{c. Amenities (Fasilitas)}

Adapun fasilitas dan akomodasi yang tersedia di Desa Gubugklakah antara lain Desa Gubugklakah memiliki rest area bagi wisatawan yang ingin melakukan perjalanan atau pendakian ke Gunung Bromo dan Gunung Semeru; Desa Gubugklakah memiliki beberapa homestay yang merupakan rumah penduduk atau masyarakat lokal yang dijadikan penginapan bagi wistawan yang berkunjung ke Desa Gubugklakah; Desa Gubugklakah memiliki beberapa tempat makan yang diusahakan oleh penduduk atau masyarakat lokal yang berupa warung atau kedai.

\section{d. Anciliary service (Pelayanan Tambahan)}

Dalam industri pariwisata, diperlukan adanya suatu organisasi atau lembaga yang mengelola suatu daya tarik agar obyek wisata dapat dikelola dan dikembangkan sehingga dapat mendatangkan banyak wisatawan. Lembaga yang ada di desa ini adalah Lembaga Desa Wisata (LADESTA) Gubugklakah yang dikelola langsung oleh Tokoh dan para 
pemuda Masyarakat Desa Gubug Klakah dibawah naungan Kepala Desa setempat dan Dinas Kebudayaan dan Pariwisata Kabupaten Malang serta melibatkan semua masyarakat di Desa Gubugklakah.

Selain empat komponen utama daya tarik wisata yang dikemukakan diatas, suatu daerah tujuan wisata (DTW) juga harus memiliki tiga syarat daya tarik wisata, yaitu:

\section{a. Ada sesuatu yang bisa dilihat (something to see)}

Ada beberapa poin yang bisa dilihat di desa ini antara lain Sepanjang jalan Desa Gubuk Klakah ini banyak terdapat perkebunan buah apel baik yang ditanam di kebun maupun di depan pekarangan rumah penduduk, budidaya jamur, buah strawberry dan tanaman hortikultura seperti tomat, bawang, dan lain-lain; Selain suasana khas pedesaan yang kental dengan pertanian, Desa Gubugklakah juga memiliki homestay yang berjajar di sepanjang jalan desa ini; Banyak pemandangan alam yang indah berupa pohon-pohon yang rindang, air terjun seperti Coban Pelangi, Coban Trisula dan aliran sungai yang merupakan muara dari air terjun tersebut.

b. Ada sesuatu yang bisa dilakukan (something to do)

Ada beberapa poin yang bisa dilakukan di desa ini antara lain Wisatawan dapat melakukan kegiatan budidaya pertanian seperti yang dilakukan di agrowisata petik buah apel, budidaya sayuran dan agrowisata sapi perah; Air terjun Coban pelangi, wisatawan dapat melakukan kegiatan outbond dan juga kegiatan arung jeram ( rafting ) dan tubbing yang bermuara di aliran sungai dari air terjun tersebut.

\section{c. Ada sesuatu yang bisa dibeli (something to buy)}

Desa Gubugklakah juga menawarkan berbagai macam bentuk paket wisata yang dikelola oleh LADESTA Gubugklakah dimana terdapat beberapa kegiatan wisata seperti Agrowisata petik buah apel, dimana apel yang dibeli bisa dipetik langsung oleh wisatawan dan harga yang dijual adalah harga jual apel yang berlaku pada saat itu; Coban Pelangi, harga tiket masuk ke coban ini bisa dikatakan sangat terjangkau bagi semua kalangan masyarakat Arung jeram atau rafting adalah kegiatan yang memadukan unsur olahraga, rekreasi, petualangan dan edukasi.

\section{Analisi IFE (Internal Factors Evaluation)}

Matriks IFE (Internal Factors Evaluation) dilakukan dengan menentukan total skor pada analisis lingkungan internal. Penentuan skor pada analisis lingkungan internal diperoleh dari hasil perkalian antara bobot dan rating. Nilai rating ditentukan berdasarkan seberapa besar pengaruh faktor-faktor internal terhadap Desa 
Gubugklakah. Adapun hasil matriks IFE pada Tabel 1 berikut.

(Internal Factors Evaluation) dapat dilihat

Tabel 1. Matriks IFE

\begin{tabular}{|c|c|c|c|c|}
\hline No. & Faktor Internal Kunci & Bobot & Rating & $\begin{array}{c}\text { Skor } \\
\text { Bobot }\end{array}$ \\
\hline & Kekuatan (S) & (Ai) & $(\mathrm{Bi})=1,2,3,4$ & $(\mathrm{Ai} \times \mathrm{Bi})$ \\
\hline A. & Gotong royong yang kuat antar anggota masyarakat & 0,15 & 4 & 0,60 \\
\hline B. & Keindahan panorama dan alam yang masih terjaga & 0,12 & 4 & 0,48 \\
\hline C. & Obyek wisata alam yang masih asli dan banyak & 0,08 & 3 & 0,24 \\
\hline D. & menawarkan paket wisata & 0,05 & 2 & 0,10 \\
\hline E. & $\begin{array}{l}\text { Tersedianya infrastruktur yang memadai (jeep dan } \\
\text { motor triil) }\end{array}$ & 0,11 & 3 & 0,33 \\
\hline $\mathrm{F}$. & $\begin{array}{l}\text { Sebagai daerah jalur wisata (transit) memberi } \\
\text { karakter yang kuat dengan wisata dan wisatawan }\end{array}$ & 0,03 & 3 & 0,09 \\
\hline G. & $\begin{array}{l}\text { Dukungan dan partisipasi tokoh masyarakat untuk } \\
\text { terlibat aktif dalam pengelola lembaga desa wisata } \\
\text { Warga siap menerima wisatawan yang meninap } \\
\text { dirumahnya sebagai homestay }\end{array}$ & 0,03 & 2 & 0,06 \\
\hline \multicolumn{2}{|r|}{ Total Skor Kekuatan } & $\mathbf{0 , 5 7}$ & 21 & 1,90 \\
\hline & Kelemahan (W) & & & \\
\hline $\mathrm{H}$. & \multirow{6}{*}{$\begin{array}{l}\text { Obyek wisata belum dikenal luas seluruhnya oleh } \\
\text { masyarakat } \\
\text { Obyek wisata masih belum dikelola secara } \\
\text { maksimal } \\
\text { Pengetahuan masyarakat terhadap desa wisata } \\
\text { masih minim } \\
\text { Sumberdaya Manusia masih rendah } \\
\text { Kurangnya pendidikan tour guide untuk wisatawan } \\
\text { mancanegara } \\
\text { Kurangnya akses transportasi dan koneksi jaringan } \\
\text { komunikasi (sinyal) }\end{array}$} & 0,12 & 2 & 0,24 \\
\hline $\mathrm{I}$. & & 0,03 & 2 & 0,06 \\
\hline $\mathrm{J}$. & & 0,13 & 2 & 0,26 \\
\hline K. & & 0,03 & 2 & 0,06 \\
\hline $\mathrm{L}$. & & 0,07 & 2 & 0,14 \\
\hline M. & & 0,05 & 3 & 0,15 \\
\hline \multicolumn{2}{|r|}{ Total Skor Kelemahan } & $\mathbf{0 , 4 3}$ & 11 & $\mathbf{0 , 9 1}$ \\
\hline \multicolumn{2}{|r|}{ Total Skor Faktor Internal } & $\mathbf{1 , 0 0}$ & 32 & 2,81 \\
\hline
\end{tabular}

Berdasarkan hasil perhitungan

matriks IFE ( Internal Factors Evaluation ), faktor strategis yang menjadi kekuatan terbesar dan paling berpengaruh bagi Desa Gubugklakah adalah gotong royong yang kuat antar anggota masyarakat dengan skor sebesar 0,60 sedangkan faktor strategis internal yang menjadi kelemahan terbesar adalah Pengetahuan masyarakat terhadap desa wisata masih minim dengan skor sebesar 0,26. Hasil analisis matriks IFE
(Internal Factors Evaluation) untuk kekuatan dan kelemahan diperoleh total skor faktor internal sebesar 2,81.

\section{Analisis EFE (External Factors Evaluation)}

\section{Matriks EFE (External Factors}

Evaluation) dilakukan dengan menentukan total skor pada analisis lingkungan eksternal. Penentuan skor pada analisis lingkungan eksternal diperoleh dari hasil 
perkalian antara bobot dan rating. Nilai

rating ditentukan berdasarkan seberapa

besar pengaruh faktor-faktor eksternal terhadap Desa Gubugklakah. Adapun hasil matriks EFE (External Factors Evaluation) dapat dilihat pada Tabel 2 berikut.

Tabel 2. Matriks EFE

\begin{tabular}{|c|l|c|c|c|}
\hline No. & \multicolumn{1}{|c|}{ Faktor Eksternal Kunci } & Bobot & Rating & $\begin{array}{c}\text { Skor } \\
\text { Bobot }\end{array}$ \\
\hline & Peluang (O) & $(\mathrm{Ai})$ & $(\mathrm{Bi})=1,2,3,4$ & (Ai x Bi) \\
\hline A. & Wisata sebagai bagian dari kebutuhan & 0,15 & 3 & 0,45 \\
B. & Banyaknya minat wisatawan kembali ke alam (back & 0,21 & 4 & 0,84 \\
C. & to nature) & 0,15 & 3 & 0,45 \\
D. & Tawaran kerjasama dengan agen perjalanan dan & 0,15 & 3 & 0,45 \\
& Pemerintah Kabupaten Malang & & & \\
E. & Terbukanya peluang studi banding ke desa wisata & 0,11 & 2 & 0,22 \\
& lain yang berada di luar Kabupaten Malang & & & \\
& Pembangunan dan pengembangan & & & \\
& pendukung & & & \\
\hline \multicolumn{1}{|c|}{ Total Skor Peluang } & $\mathbf{0 , 7 7}$ & $\mathbf{1 5}$ & $\mathbf{2 , 4 1}$ \\
\hline & Ancaman (T) & & & 0,10 \\
\hline F. & Adanya budaya asing yang dapat menggeser budaya & 0,05 & 2 & 0,22 \\
G. & lokal Skor Faktor Eksternal & 0,11 & 2 & 0,04 \\
H. & Loyalitas pengunjung & 0,02 & 2 & 0,15 \\
I. & Tercemarnya lingkungan & 0,05 & 3 & $\mathbf{2 , 9 2}$ \\
& Narkoba masuk desa & $\mathbf{1 , 0 0}$ & $\mathbf{2 3}$ & \\
\hline
\end{tabular}

Berdasarkan hasil perhitungan matriks EFE (External Factors Evaluation) faktor eksternal yang menjadi peluang terbesar bagi Desa Gubugklakah adalah banyaknya minat wisatawan kembali ke alam (back to nature) dengan skor sebesar 0,84 sedangkan faktor eksternal yang menjadi ancaman terbesar bagi Desa Gubugklakah adalah loyalitas pengunjung dengan skor sebesar 0,22. Hasil analisis matriks EFE untuk peluang dan ancaman diperoleh total skor faktor eksternal sebesar 2,92 .

\section{Analisis Matriks Internal-Eksternal (I-E)}

Berdasarkan hasil yang diperoleh dari matriks IFE (Internal Factors Evaluation) dan matriks EFE (External 
Factors Evaluation), maka dapat disusun matriks Internal-Eksternal (I-E). Total skor bobot pada matriks IFE sebesar 2,81 dan total skor bobot pada matriks EFE sebesar 2,92 dimana hasil yang diperoleh tersebut menempatkan Desa Gubugklakah berada pada sel V, maka strategi terbaik yang dapat dilaksanakan Desa Gubugklakah dalam pengembangan sebagai desa wisata adalah Growth and Stability Strategy Untuk divisi seperti ini strategi yang paling tepat adalah melaksanakan strategi intensif dan integrasi. Strategi intensif terdiri dari strategi Penetrasi Pasar (Market Penetration), Pengembangan Pasar (Market Development) dan Pengembangan Produk
(Product Development). Strategi integrasi terdiri dari integrasi kedepan (Forward Integration), integrasi kebelakang (Backward Integration) dan integrasi horizontal (Horizontal Integration).

\section{Analisis Matriks SWOT (Strength, Weakness, Opportunities, Threats)}

Analisis ini menggunakan data yang telah diperoleh matriks IFE (Internal Factors Evaluation) dan EFE (External Factors Evaluation) sebelumnya. Hasil matriks analisis SWOT (Strength, Weakness, Opportunities, Threath) dapat dilihat pada Tabel 3 berikut:

Tabel 3. Matriks SWOT

\begin{tabular}{|l|c|c|}
\hline IFE & Kekuatan (S) & Kelemahan (W) \\
1. Gotong royong yang kuat & 1. Obyek wisata belum dikenal \\
antar anggota masyarakat & luas seluruhnya oleh \\
2. Keindahan panorama dan & masyarakat \\
alam yang masih terjaga & 2. Obyek wisata masih belum \\
3. Obyek wisata alam yang & dikelola secara maksimal \\
masih asli dan banyak & 3. Pengetahuan masyarakat \\
menawarkan paket wisata & terhadap desa wisata masih \\
& 4. Tersedianya infrastruktur & minim \\
yang memadai (jeep dan & 4. Sumberdaya Manusia masih \\
motor triil) & rendah \\
& 5. Sebagai daerah jalur & 5. Kurangnya pendidikan tour \\
wisata (transit) memberi & guide untuk wisatawan \\
karakter yang kuat & mancanegara \\
dengan wisata dan & 6. Kurangnya akses \\
wisatawan & transportasi dan koneksi \\
& 6. Dukungan dan partisipasi & jaringan komunikasi (sinyal) \\
\hline
\end{tabular}




\begin{tabular}{|c|c|c|}
\hline & $\begin{array}{l}\text { tokoh masyarakat untuk } \\
\text { terlibat aktif dalam } \\
\text { pengelola lembaga desa } \\
\text { wisata } \\
\text { 7. Warga siap menerima } \\
\text { wisatawan yang meninap } \\
\text { dirumahnya sebagai } \\
\text { homestay }\end{array}$ & \\
\hline $\begin{array}{l}\text { Peluang (O) } \\
\text { 1. Wisata sebagai bagian } \\
\text { dari kebutuhan } \\
\text { 2. Banyaknya minat } \\
\text { wisatawan kembali ke } \\
\text { alam (back to nature) } \\
\text { 3. Tawaran kerjasama } \\
\text { dengan agen perjalanan } \\
\text { dan Pemerintah } \\
\text { Kabupaten Malang } \\
\text { 4. Terbukanya peluang } \\
\text { studi banding ke desa } \\
\text { wisata lain yang berada } \\
\text { di luar Kabupaten } \\
\text { Malang } \\
\text { 5. Pembangunan dan } \\
\text { pengembangan sarana } \\
\text { pendukung }\end{array}$ & \begin{tabular}{l}
\multicolumn{1}{c}{ Strategi SO } \\
1. Pengembangan desa \\
wisata dengan \\
partisipasi aktif yang \\
melibatkan seluruh \\
stakeholder berdasarkan \\
pada karakteristik \\
masyarakat desa \\
setempat. \\
(S1,S6,S7,O3,O4,O5) \\
Mengembangkan paket \\
wisata yang lebih \\
menarik dengan \\
mengoptimalkan \\
keindahan panorama \\
alam berbasis pada \\
pelestarian lingkungan \\
(S2,S3,S5,O1,O2,,O5)
\end{tabular} & $\begin{array}{l}\text { Strategi WO } \\
\text { 1. Memberikan pendidikan } \\
\text { dan pelatihan desa wisata } \\
\text { kepada seluruh masyarakat } \\
\text { untuk kepuasan wisatawan } \\
\text { (W2,W3,W4,W5,01.02) } \\
\text { 2. Melakukan kerjasama } \\
\text { dengan berbagai } \\
\text { stakeholder terkait untuk } \\
\text { pengembangan potensi desa } \\
\text { wisata dan mengembangkan } \\
\text { produk lokal } \\
\text { (W1,W2,W6,03,04,O5) }\end{array}$ \\
\hline $\begin{array}{l}\text { Ancaman }(\mathbf{T}) \\
\text { 1.Adanya budaya asing } \\
\text { yang dapat menggeser } \\
\text { budaya lokal } \\
\text { 2. Loyalitas pengunjung }\end{array}$ & \begin{tabular}{l}
\multicolumn{1}{c}{ Strategi ST } \\
1. Memberikan \\
penyuluhan kepada para \\
wisatawan untuk ikut \\
melestarikan lingkungan
\end{tabular} & $\begin{array}{l}\text { Strategi WT } \\
\text { 1. Memberikan penguatan } \\
\text { kepada masyarakat bahwa } \\
\text { begitu berharganya } \\
\text { kebudayaan lokal dan desa }\end{array}$ \\
\hline
\end{tabular}




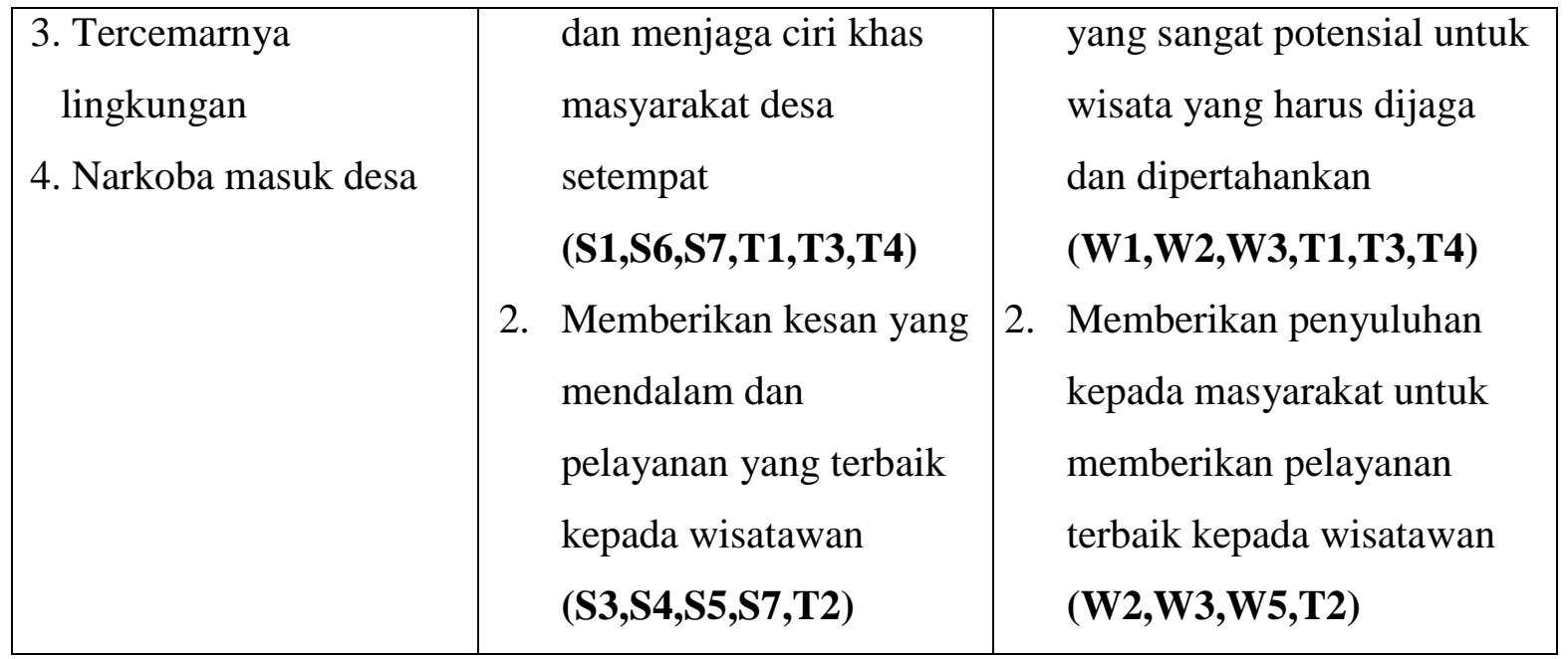

Berdasarkan hasil pada analisis matriks SWOT, maka dapat diperoleh empat alternatif strategi yang dapat diambil dalam pengembangan Desa Gubugklakah sebagai desa wisata antara lain sebagai berikut:

\section{a. Strategi SO}

Strategi SO yaitu strategi yang menggunakan kekuatan untuk memanfaatkan keuntungan dari peluang yang ada, terdiri dari:Pengembangan desa wisata dengan partisipasi aktif yang melibatkan seluruh stakeholder berdasarkan pada karakteristik masyarakat desa setempat.

(S1,S6,S7,03,04,05);Mengembangkan paket wisata yang lebih menarik dengan mengoptimalkan keindahan panorama alam berbasis pada pelestarian lingkungan. (S2,S3,S5,01,02,,05)

\section{b. Strategi WO}

Strategi WO yaitu strategi yang memperkecil kelemahan dengan memanfaatkan keuntungan dari peluang yang ada, terdiri dari:Memberikan pendidikan dan pelatihan desa wisata kepada seluruh masyarakat untuk kepuasan wisatawan.

(W2,W3,W4,W5,01.02).

Melakukan kerjasama dengan berbagai stakeholder terkait untuk pengembangan potensi desa wisata dan mengembangkan produk lokal. (W1,W2,W6,03,04,05)

\section{c. Strategi ST}

Strategi ST yaitu strategi menggunakan kekuatan untuk mengatasi ancaman, terdiri dari: Memberikan penyuluhan kepada para wisatawan untuk ikut melestarikan lingkungan dan menjaga ciri khas masyarakat desa setempat (S1,S6,S7,T1,T3,T4). Memberikan kesan yang mendalam dan pelayanan yang terbaik kepada wisatawan $(\mathbf{S 3 , S 4 , S 5 , S 7 , T 2 )}$

\section{d. Strategi WT}

Strategi WT yaitu strategi meminimalkan kelemahan dan mengatasi ancaman, terdiri dari:Memberikan penguatan kepada masyarakat bahwa begitu 
berharganya kebudayaan lokal dan desa yang sangat potensial untuk wisata yang harus dijaga dan dipertahankan (W1,W2,W3,T1,T3,T4). Memberikan penyuluhan kepada masyarakat untuk memberikan pelayanan terbaik kepada wisatawan (W2,W3,W5,T2).

\section{Analisis Matriks QSPM}

Berdasarkan hasil matriks QSPM, nilai daya tarik tertinggi terdapat pada strategi 2 dengan jumlah total daya tarik (TAS) sebesar 5,97. Nilai daya tarik tertinggi kedua terdapat pada strategi 1 dengan jumlah TAS sebesar 5,50 dan tertinggi ketiga terdapat pada strategi 4 dengan total TAS sebesar 5,07. Sedangkan nilai daya tarik terendah terdapat pada strategi 3 dengan total TAS sebesar 4,97.

\section{KESIMPULAN}

Berdasarkan hasil penelitian dan pembahasan tentang strategi pengembangan desa wisata pada Desa Gubugklakah diperoleh kesimpulan bahwa Desa Gubugklakah merupakan suatu desa yang memiliki potensi besar untuk dijadikan sebagai desa wisata karena memiliki suatu objek dan daya tarik wisata dan menempatkan desa ini pada sel $\mathrm{V}$ pada matriks IE, maka strategi terbaik yang dapat dilaksanakan adalah Growth and Stability Strategy, dimana implementasi strategi yang paling tepat adalah melaksanakan strategi intensif dan integrasi.

\section{DAFTAR PUSTAKA}

Anonymous. 2001. Pembangunan Kawasan Unggulan Minat Khusus Petualangan di Kalimantan Timur. Jakarta: Direktorat Jenderal Pengembangan Produk Wisata.

Anonymous. 1999. Konsep Awal Pariwisata Inti Rakyat. Jakarta: Depparsenibud.

Arikunto, Suharsimi. 2007. Prosedur Penelitian suatu pendekatan Praktek. Jakarta: Rineka Cipta.

David, Fred R. 2002. Manajemen Strategis. Prenhallindo. Jakarta.

I Made Adidharmawan, I Made Sarjan.. 2014. E-Jurnal Agribisnis dan Agrowisata ISSN: 2301-6523 Vol. 3, No. 1

Jauch dan Glueck. 1993. Manajemen Strategis dan Kebijakan Perusahaan. Jakarta: Erlangga.

Karyono, A. Hari. 1997. Kepariwisataan. Jakarta: Grasindo.

Kinnear, T.L. and Taylor. 1991. Marketing Research:An Applied Approach. Fourth Edition. USA: Mc Graw Hill.

Kotler, Philip. 1997. Manajemen Pemasaran. Analisis Perencanaan, Implementasi, dan Kontrol. Jakarta: Prenhallindo.

Marpaung, Happy. 2013. Pengetahuan Kepariwisataan. Bandung: Alfabeta.

Pendit, Nyoman S. 1994. Ilmu Pariwisata Sebuah Pengantar Perdana. Jakarta: Pradnya Paramita.

Pearce dan Robinson. 1997. Manajemen Strategik, Formulasi, Implementasi dan Pengendalian. Jilid Satu. Jakarta: Binarupa Aksara.

Rangkuti, Freddy. 2002. Analisis SWOT: Teknik Membeda Kasus Bisnis. Jakarta: Gramedia Pustaka Utama.

Soeratno, Lincoln. 2008. Warta Penelitian dan Pengembangan Pertanian Vol.2 No.1. Jakarta. 
Sznajder L, Prezezbórska F, dan
Scrimgeour. 2009. Agritourism, European J Tourism Res. 2 Zhaoping: Xuling L.

Yoeti. 2006. Pariwisata Untuk Semua. Jakarta. Gramedia.

http://www.pnpmmandiri.org/index.php?opt ion $=$ com_content $\&$ view $=$ article $\& i d=$ 35:978-desa Diakses: 13 Januari 2016 pukul 12.30 WIB.
http://id.wikipedia.org/wiki/Desa_wisata.

Diakses: 13 Januari 2016 pukul 23:00 WIB.

http://id.wikipedia.org/wiki/Analisis_SWOT

Diakses: 13 Januari 2016 pukul 15:20 WIB.

http://id.wikipedia.org/wiki/Desa_wisata.

Diakses: 20 Januari 2016 pukul 15:15 WIB.

http://www.bpkp.go.id/unit/hukum/perpres/ 2005/2007-05.pdf. Diakses: 20 Januari 2016 pukul 10:45 WIB. 